\title{
Asia-Pacific Moving towards the Ratification of the Treaty on the Prohibition of Nuclear Weapons*
}

\author{
Hong Thao Nguyen ${ }^{* *}$
}

The new Treaty on Prohibition of Nuclear Weapons ("TPNW") opened for signature on September 20, 2017. It will enter into force in 90 days after getting 50 instruments of ratification. This fact shows that Asia-Pacific is in the forward position to totally eliminate nuclear weapons in the world for the peace, security and human well-being. How to move forward the process of ratifying the TPNW? In order to clarify this question, the author will focus on the following three parts: 1) Asia-Pacific and International Humanitarian Law; 2) Treaty on the Prohibition of Nuclear Weapons - a step towards the nuclear disarmament; and 3) Ratification of TPNW.

\section{Keywords}

TPNW, NPT, Nuclear Weapons, IHL, ICRC, Nuclear Weapons Free Zone

\section{Introduction}

The new Treaty on Prohibition of Nuclear Weapons ("TPNW") opened for signature on September 20, 2017. It will enter into force in 90 days after getting 50 instruments of ratification. After one year, 19 ratification instruments were deposited, near one third of them from Asia-Pacific countries (Thailand, Palau, Vietnam, New Zealand, Cook Island and Samoa). ${ }^{1}$ This fact shows that Asia-Pacific is in the forward position to totally eliminate nuclear weapons in the world for the peace, security and human well-being. How to move forward the process of ratifying the TPNW? It is a big question before the International Committee of the Red Cross ("ICRC"), other

* This paper is revised and updated version of the author's speech at the ICRC Regional Conference on International Humanitarian Law in Asia-Pacific: Taking Stock, Moving Forward, Jakarta on September 26-27, 2018.

** Professor of International Law at National University of Vietnam-Hanoi and Diplomacy Academy of Vietnam (DAV); Member of the International Law Commission. The author may be contacted at: nguyenhongthao57@gmail.com DOI: http://dx.doi.org/10.14330/jeail.2018.11.2.11

1 ICAN, Signature/ratification status of the Treaty on the Prohibition of Nuclear Weapons, available at http://www. icanw.org/status-of-the-treaty-on-the-prohibition-of-nuclear-weapons (last visited on Nov. 12, 2018). 
organizations and civil society to build a strategy to assist governments in achieving the final goal.

In order to clarify this question, the author will focus on the following three parts: 1) Asia-Pacific and International Humanitarian Law; 2) Treaty on the Prohibition of Nuclear Weapons - a step towards the nuclear disarmament; and 3) Ratification of TPNW.

\section{Asia-Pacific, Nuclear Weapons and International Humanitarian Law}

Asia-Pacific is the region that heavily suffered from the weapons of mass destruction. The first and unique nuclear attacks in 1945 killed about 140,000 people in Hiroshima, and a further 74,000 in Nagasaki. ${ }^{2}$ In the following years, terrible side effects from the radiation negatively affected human well-being and resulted in an unrecoverable environment. The first cluster munitions were widely used in the Vietnam War (196575). American forces deployed roughly 800,000 cluster bombs during the period. ${ }^{3}$ In addition, 7.85 million tons of bombs were thrown over Vietnam, which is triple of the whole bombs used by countries in World War II and compatible to the power of 250 nuclear bombs dropped on Hiroshima. The use of nuclear weapons, cluster munitions or land mines brought terrible unrecoverable consequences to civilians, contradicts principles of international humanitarian law ("IHL") and the desire of human beings to live in a safe and clean environment.

Facing the challenges of 'war crimes,' IHL has also arisen to punish those who use methods that unnecessarily increase the suffering caused by warfare. ${ }^{4}$ With the huge effort of the ICRC, the world's guardian of IHL, Asia-Pacific nations have a considerable contribution in building, compliance and implementation of IHL. The Geneva Conventions adopted on August 12, $1949^{5}$ and the Additional Protocols of

2 ICAN, Hiroshima and Nagasaki: 7 things you should know, available at http://www.icanw.org/action/hiroshima-andnagasaki-7-things-you-should-know (last visited on Nov. 12, 2018).

3 Human Rights Watch, Time of Cluster Munitions Use (2008), available at http://www.hrw.org/sites/default/files/ related-material/Timeline-Cluster_-Use_05.08.pdf(last visited on Nov. 12, 2018).

4 B. Docherty, The Time is Now: A Historical Argument for a Cluster Munitions Convention, 20 Harv. Hum. RTS. J. 53 (2007).

5 ICRC, Geneva Conventions of 12 August 1949, available at https://www.icrc.org/eng/assets/files/publications/icrc002-0173.pdf (last visited on Nov. 12, 2018). 
1977 and 2005 supplementing to the Geneva Conventions ${ }^{6}$ created a core of IHL. They imposed a conventional obligation of ending the use of weapons that cause heavy suffering to civilians in wars. Those obligations also own the customary character and are binding even on non-parties of the Geneva Conventions. Any nation that has ratified the Geneva Conventions but not the Protocols is still bound by all provisions of the Conventions. ${ }^{7}$ Article 35 of the Protocol I prohibits not only to "employ weapons, projectiles and material and methods of warfare of a nature to cause superfluous injury or unnecessary suffering," but also "to employ methods or means of warfare that cause widespread, long-term, and severe damage to the natural environment." methods or means of warfare is not unlimited." On the basis of this rule, new conventions on arms control have been developed such as Nuclear Non-Proliferation Treaty 1968 ("NPT"), Biological Weapons Convention 1972 (“BWC"), ${ }^{10}$ Convention on Prohibitions or Restrictions on the Use of Certain Conventional Weapons 1980, ${ }^{11}$ Chemical Weapons Convention 1993 (“CWC”), ${ }^{12}$ Comprehensive Test Ban Treaty 1996 ("CTBT"), 13 Convention on the Prohibition of the Use, Stockpiling, Production and Transfer of Anti-personnel Mines 1997, ${ }^{14}$ Cluster Munitions Convention 2008, ${ }^{15}$ Arm Trade Convention 2013, ${ }^{16}$ and Treaty on the Prohibition of Nuclear Weapons 2017.

Asia-Pacific has three among five nuclear weapons free zones ("NWFZs") in the world, except Antarctica and Outer Space such as: South Pacific Nuclear Weapons

$6 \quad I d$.

7 American Red Cross, Summary of the Geneva Conventions of 1949 and Their Additional Protocols, April 2011,

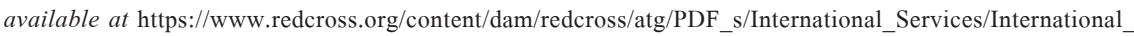
Humanitarian_Law/IHL_SummaryGenevaConv.pdf (last visited on Nov. 12, 2018).

8 IRCR, Protocol Additional to the Geneva Conventions of 12 August 1949, May 2010, at 30.

9 Arms Control Association, Nuclear Nonproliferation Treaty (NPT), available at https://www.armscontrol.org/treaties/ nuclear-nonproliferation-treaty (last visited on Nov. 12, 2018).

10 UNODA, Convention on the Prohibition of the Development, Production, Stockpiling and Use of Chemical Weapons and on their Destruction, available at http://disarmament.un.org/treaties/t/bwc (last visited on Nov. 12, 2018).

11 UNODA, Convention on Prohibitions or Restrictions on the Use of Certain Conventional Weapons, available at http:// disarmament.un.org/treaties/t/ccwc (last visited on Nov. 12, 2018).

12 Chemical Weapons Convention (CWC), available at http://disarmament.un.org/treaties/t/cwc (last visited on Nov. 12, 2018).

13 Comprehensive Test Ban Treaty Status of signature and ratification (Not yet in force; 167 ratifying States among 184 signatory States), available at https:/www.ctbto.org/map/\#status (last visited on Nov. 12, 2018).

14 Landmine and Cluster Munition Monitor and ongoing public updates, available at http://www.icbl.org/en-gb/the-treaty/ treaty-status.aspx (last visited on Nov. 12, 2018).

15 Convention on Cluster Munitions, available at $\mathrm{http}: / /$ www.clusterconvention.org (last visited on Nov. 12, 2018).

16 UNODA, Arms Trade Treasty, available at http://disarmament.un.org/treaties/t/att (last visited on Nov. 12, 2018).

17 ICAN, supra note 1. 
Free Zone Treaty 1985 (Treaty of Rarotonga) ${ }^{18}$, Southeast Asian Nuclear-WeaponFree-Zone 1995 (“SEANWFZ”) Treaty (Bangkok Treaty), and Treaty creating a zone free of nuclear weapons in Central Asia 2009. ${ }^{19}$ Also, Mongolia is Nuclear Weapons Free State. The other NWFZs are located in Africa ${ }^{20}$ and Latin America. ${ }^{21}$

The Protocol to the Bangkok Treaty is open for signature by China, France, Russia, the UK, and the US. These nuclear weapons states would undertake to respect the treaty. They must also comply the Protocol to the Bangkok Treaty. ${ }^{22}$ They would also undertake not to use or threaten to use nuclear weapons against any State Party to the treaty and not to use or threaten to use nuclear weapons within the SEANWFZ. ${ }^{23}$ Different from other four NWFZ treaties, the Bangkok Treaty provides two additional elements. One is the zone of application which includes the continental shelves and EEZ of the contracting parties. ${ }^{24}$ The other is the negative security assurance, which implies a commitment by the nuclear weapons states not to use nuclear weapons against any contracting State or Protocol Party within the zone of application. ${ }^{25}$ This is why some nuclear weapon states have not yet signed the Protocol.

On November 19, 2011, during the ASEAN Summit, the ASEAN members and the nuclear-weapon states reached an agreement to pave the way for the peaceful use of nuclear powers, for complete signature and ratification of the 1995 Protocol. $^{26}$ The ASEAN countries and Australia, China, India, Japan, Korea, the US, Russia and New Zealand unanimously declared to welcome the conclusion of the negotiation between the ASEAN and the Nuclear Weapon States ("NWSs") to enable the NWSs to accede to the SEANWFZ protocol. This determination is confirmed by the Chairman's statement on the 32nd ASEAN Summit in April 2018. ${ }^{27}$ The ASEAN remains its

18 South Pacific Nuclear Weapons Free Zone Treaty (Treaty of Rarotonga), available at https://www.armscontrol.org/ treaties/south-pacific-nuclear-weapons-free-zone-treaty (last visited on Nov. 12, 2018).

19 Treaty creating a zone free of nuclear weapons in Central Asia, available at https://www.iaea.org/newscenter/news/ nuclear-weapon-free-zone-central-asia (last visited on Nov. 12, 2018).

20 The African Nuclear-Weapons-Free Zone Treaty, available at http://disarmament.un.org/treaties/t/pelindaba (last visited on Nov. 12, 2018).

21 The Latin America Nuclear Weapons Free Zone Treaty (Treaty of Tlatelolco), available at http://disarmament.un.org/ treaties/t/tlatelolco (last visited on Nov. 12, 2018).

221995 Protocol to the Treaty on the Southeast Asia nuclear weapon-free zone, art. 1.

23 Id. art. 2.

241995 Treaty on the Southeast Asia nuclear weapon-free zone, art. 1(1), available at http://www.aseansec.org/3636. htm (last visited on Nov. 12, 2018).

251995 Protocol, supra note 22, art. 2.

26 ASEAN Chairman's Statement of the Summit Bali, Indonesia, November 19, 2011: qף 36-37, available at https:// www.asean.org/wp-content/uploads/archive/documents/19th summit/EAS-CS.pdf (last visited on Nov. 12, 2018).

27 Chairman's statement on the 32nd ASEAN Summit in April 2018, 10, available at https://asean.org/storage/2018/04/ Chairmans-Statement-of-the-32nd-ASEAN-Summit.pdf (last visited on Nov. 12, 2018). 
commitment to preserve the Southeast Asian region as a NWFZ. That is also free from all other weapons of mass destruction as enshrined in the SEANWFZ Treaty and the ASEAN Charter. The ASEAN wants to continuously engage the NWSs and intensify the on-going efforts of all Parties to resolve the outstanding issues in accordance with the objectives and principles of the SEANWFZ Treaty. ${ }^{28}$

In the final draft of "Crimes against Humanity" that will be submitted to the UN General Assembly in 2019 for consideration, the International Law Commission ("ILC") defines "crime against humanity" as "means any of the following acts when committed as part of a widespread or systematic attack directed against any civilian population, with knowledge of the attack...; (k) Other inhumane acts of a similar character intentionally causing great suffering, or serious injury to body or to mental or physical health." ${ }^{29}$ In this regard, the possession and use of nuclear weapons obviously will be considered as a crime against humanity, which must be punished under international law.

The campaign for the ratification of the Treaty on the Prohibition of Nuclear Weapons among Asia Pacific nations will encourage the treaty to enter into force as soon as possible and serve a basis for progress towards nuclear disarmament. AsiaPacific countries should be in line with other nations and organizations such as ICRC and ILC in the struggle for erasing nuclear weapons from the green Earth.

\section{Treaty on the Prohibition of Nuclear Weapons: A Step towards the Nuclear Disarmament}

Mankind is trying to totally abolish nuclear weapons. The NPT prohibits manufacturing and producing nuclear weapons. It emphasizes its objective to reduce and stop the nuclear arm race. However, it does not illegalize nuclear weapons. The CTBT has provisions on the prohibition of nuclear tests, but it has not entered into force yet. Until now there are 167 ratifying States among 184 signatory States. ${ }^{30}$ In accordance with Article XIV of the CTBT, the Convention will enter into force if it get the ratifications of 44 States listed in the Annex 2 to the Treaty. Among the required

28 Id.

29 U.N. Doc. A/CN.4/L.892 (May 26, 2017), available at http://legal.un.org/docs/index.asp?symbol=A/CN.4/L.892 (last visited on Nov. 12, 2018).

30 CTBT Status of signature and ratification, available at https:/www.ctbto.org/map/\#status (last visited on Nov. 12, 2018). 
list of ratifying States, there are six nuclear weapons states (China, North Korea, India, Israel, Pakistan and the US) and two non-nuclear States (Egypt and Iran). ${ }^{31}$ The International Court of Justice ("ICJ") in its advisory opinion on Legality of the Threat or Use of Nuclear Weapons in 1996 accused of the threat by or use of nuclear weapons that has not reconciled with the principles of international humanitarian law. ${ }^{32}$ Today, however, the ICJ has not definitely concluded the legality or illegality of the use of nuclear weapons by a State in an extreme circumstance of self-defence, in which its very survival would be at stake. ${ }^{33}$ While the two Conventions on the weapons of mass destruction such as the Biological Weapons Convention 1972 ("BWC") ${ }^{34}$ and the Chemical Weapons Convention 1993 ("CWC") 35 have banned the use of biological and chemical weapons, there is not any explicit prohibition of use of nuclear weapons in these conventions. Not all of nuclear-weapon-free-zone treaties contain a prohibition on the development of nuclear weapons. They create a large gap in the nuclear disarmament process. The TPNW addresses this shortcoming, clearly banning the development, testing, producing, manufacturing, possessing, stockpiling, transferring and using or threatening to use of nuclear weapons. ${ }^{36}$ It also prohibits any activity to assist, encourage anyone to engage in any activity prohibited or allow having, stationing, installation or deployment of any nuclear weapons or other nuclear explosive devices in territory of State Party or at any place under its jurisdiction or control. ${ }^{37}$ The new treaty reaffirms that any use of nuclear weapons should be contrary to the rules of international law applicable to armed conflicts, in particular, the principles of IHL. ${ }^{38}$ The legally binding prohibition of nuclear weapons will constitute an important contribution to building the world free of the nuclear weapons. ${ }^{39}$ The new treaty is perfectly supplementary to the NPT. It will be one of the effective measures to realize nuclear disarmament provided by Article VI of the

31 Report of the Conference on Facilitating the Entry into Force of the Comprehensive Nuclear-Test-Ban Treaty, Sept. 20, 2017, CTBT-Art.XIV/2017/6, and its Annex - Final Declaration and Measures to Promote the Entry into Force of the Comprehensive Nuclear-Test-Ban Treaty, @ 4, available at https://www.ctbto.org/fileadmin/user_upload/Art_14_2017/ CTBT_Art_XIV_2017_6.pdf (last visited on Nov. 12, 2018).

32 Legality of the Threat or Use of Nuclear Weapons, Advisory Opinion, 1996 I.C.J. Rep. ๆ 266 (July 8).

33 Id. $\uparrow 105$.

34 Biological Weapons Convention (BWC), available at http://disarmament.un.org/treaties/t/bwc (last visited on Nov. 12, 2018).

35 Chemical Weapons Convention (CWC), available at $\mathrm{http}: / /$ disarmament.un.org/treaties/t/cwc (last visited on Nov. 12, 2018).

36 TPNW - Prohibition, art. 1(a-f), U.N. Doc. A/CONF.229/2017/8, available at http://undocs.org/A/CONF.229/2017/8 (last visited on Nov. 12, 2018).

37 Id. art. $1(\mathrm{e}-\mathrm{g})$.

38 Id. pmbl.

39 Id. 
NPT. It also confirms an "obligation to pursue in good faith and bring to a conclusion negotiations leading to nuclear disarmament in all of its aspects under strict and effective international control." ${ }^{40}$

The UN Secretary General, António Guterres, in his new agenda for disarmament of 2018 said: "The existential threat that nuclear weapons pose to humanity must motivate us to accomplish new and decisive action leading to their total elimination. We owe this to the Hibakusha-the survivors of nuclear war - and to our planet." ${ }^{\text {"11 }}$ To reach this aim, the ratification of the TPNW is a necessary task.

\section{Ratification of TPNW}

Asia-Pacific must fix the priority goal to become the region prohibiting nuclear weapons. To achieve this goal, some measures could be envisaged and implemented. The first is to mobilize the non-nuclear weapons countries to ratify the TPNW. Thailand is the first country to ratify the TPNW at the same day of opening for signature on September 20, 2017. It has been leading the nuclear weapons free world campaign and the host country of the Bangkok Treaty. New Zealand also ratified it on July 31, 2018 to pursue its "long-standing commitment to international nuclear disarmament efforts." ${ }^{42}$ New Zealand joined the South Pacific Nuclear Weapons Free Zone Treaty on August 6, 1985. The New Zealand Nuclear Free Zone, Disarmament and Arms Control Act 1987 declared New Zealand as a nuclear free zone. ${ }^{43}$ The Nuclear Test case in $1974^{44}$ and the Rainbow Warrior Arbitration $1987^{45}$ demonstrated New Zealand's determination towards a Nuclear-Weapon-Free World. This country is the co-author with Brazil, Egypt, Ireland, Mexico, Slovenia, South Africa and Sweden of the joint declaration titled, "Towards a Nuclear-Weapon-Free World: The Need for a New Agenda" in 1998. ${ }^{46}$ Palau, a small island country, which ratified the TPNW on May 3, 2018, is the first country in the world that approved the nuclear-free

40 Supra note $32, \boldsymbol{9} 105 \mathrm{~F}$.

41 UNODA, Securing our common future-An Agenda for Disarmament, at vii, available at http://www.un.org/ disarmament/sg-agenda (last visited on Nov. 12, 2018).

42 See NZ signs UN anti-nuke treaty, NewshuB, Sept. 21, 2017, available at https://www.newshub.co.nz/home/world/ 2017/09/nz-signs-un-anti-nuke-treaty.html (last visited on Nov. 12, 2018).

43 New Zealand Nuclear Free Zone, Disarmament, and Arms Control Act.

44 Supra note 32 , at 9253.3

4526 I.L.M. 1346.

46 J. Singh, M. Sethi \& G. Jacobs, Abolishing Nuclear Weapons, Futures, J. Pol'y, Planning \& Future Stud. (2007). 
constitution $^{47}$ in $19811^{48}$

Vietnam submitted the ratification instrument to the UN on May 17, 2018, as the tenth in the list of ratification of the TPNW. ${ }^{49}$ It is noticeable that Vietnam ratified all three nuclear weapons free conventions, the NPT in 1982 and the CTBT in 2006 and the TPNW in 2018. The provisions of the TPNW are compatible with the Vietnamese laws and regulations in this field. Article 12 of the Vietnamese Law on Nuclear Energy ${ }^{50}$ and Articles 1, 4 and 27 of the Law on National Defense prohibit the development, testing, producing, manufacturing, otherwise acquiring, possessing or stockpiling nuclear weapons or other nuclear explosive devices; transferring to any recipient whatsoever nuclear weapons or other nuclear explosive devices or control over such weapons or explosive devices directly or indirectly; receiving the transfer of or control over nuclear weapons or other nuclear explosive devices directly or indirectly; using or threatening to use nuclear weapons or other nuclear explosive devices; assisting, encouraging or inducing, in any way, any assistance, in any way, from anyone to engage in any activity prohibited; and allowing any stationing, installation or deployment of any nuclear weapons or other nuclear explosive devices in its territory or at any place under its jurisdiction or control. These enumerate almost the same prohibitions of nuclear weapons use as listed in Article 1 of the TPNW. By ratifying the TPNW, "Vietnam support[ed] any imitative to prevent development, manufacture, stockpile and use mass destruction weapons."

The second is to encourage States to conclude with the International Atomic Energy Agency ("IAEA") a comprehensive safeguards agreement before and in parallel with the process of accession to the TPNW. Articles 2 and 3 of the TPNW stipulate the obligations of States to declare the non-possession of any nuclear weapons or other nuclear explosive devices in its territory or the non-installation of nuclear weapons and other nuclear explosive devices of foreign States in any place under its jurisdiction or control. As States must conclude and implement comprehensive safeguards agreements with the IAEA, those who have a good relationship with the IAEA are easy to accept ratification of the treaty. Vietnam is a typical example, who signed a similar agreement with the IAEA in 1990 and fulfilled its obligation to declare the transparency on nuclear use. Article 4 of the TPNW has

47 Palau Const. 1979, § 6, available at http://www.paclii.org/pw/constitution.html (last visited on Nov. 12, 2018).

48 Trusteeship Mission reports on Palau voting, 27 (2) UN ChronicLe (June 1990).

49 ICAN, supra note 1.

50 Vietnamese Law on Nuclear Energy, art. 12.

51 Panjaj Kumar, Vietnamese Defense White Paper 2009, Institute for Defense Studies and Analyses (IDSA), Dec. 31, 2009, available at $\mathrm{http} / /$ idsa.in/idsacomments/VietnameseDefenceWhitePaper2009_pkjha_311209 (last visited on Nov. 12, 2018). 
not caused any difficulty to Vietnam, because it consistently maintains the "three nos policy"52 including non-allowing any foreign country to use its territory against other third country. In August 2007, Vietnam signed the Additional Protocol to the safeguards agreement with the IAEA to meet any requirement of supervision over nuclear reactors and of highest standards of the IAEA.

The third is to clarify the benefits of ratification of the TPNW to developing countries. The TPNW does not demand any financial expense from developing countries without nuclear weapons. Developing countries have not borne the cost for destruction or supervision of nuclear weapons or other nuclear explosive devices, owned by nuclear States. ${ }^{53}$ State Parties only bear the costs of the regular meetings, the review conferences (in 6 years), the extraordinary meetings and the costs incurred by the UN Secretary-General in the circulation of declarations under Article 2, reports under Article 4 and proposed amendments under Article 10 of this Treaty in accordance with the UN scale of assessment adjusted appropriately. ${ }^{54}$ These costs are not significant. Meanwhile, the TPNW respects the independence, sovereignty and impeccable territory of States Parties, the non-interference into their internal affairs, the equitable and mutual benefits as well as the settlement of disputes by peaceful means. ${ }^{55}$ The TPNW addresses: "Nothing in this Treaty shall be interpreted as affecting the inalienable right of its States Parties to develop research, production and use of nuclear energy for peaceful purposes without discrimination." 56 It also stipulates the possibility of withdrawal for a State Party if "it decides that extraordinary events related to the subject matter of the Treaty have jeopardized the supreme interests of its country. ${ }^{, 57}$ Those provisions assure favorable conditions for developing non-nuclear weapons countries in using nuclear energy for the purpose of peace and social-economic development. Non-nuclear weapons countries thus have the right to require States using nuclear weapons to bear responsibility in "adequately providing age- and gender-sensitive assistance, without discrimination, including medical care, rehabilitation and psychological support, as well as provide for their social and economic inclusion."

52 N. Chapman, Mechanisms of Vietnam's Multidirectional Foreign Policy, 36:2 J. Current Southeast Asian AfF. 38. (2017)

53 TPNW art. 9.3.

54 Id. art. $9.1 \& 2$.

55 Id. art. 11.1.

$56 \quad I d$. pmbl.

57 Id. art. 17.1.

58 Id. art. 6(1). 
contaminated areas. ${ }^{59}$ They shall also have the right to seek and receive assistance, where feasible, from other States Parties. ${ }^{60}$

\section{Conclusion}

The more ratifications developing countries will make, the more pressure nuclear weapons States will take. However, the final goal to totally eliminate nuclear arsenal in the world cannot be achieved without the active participation of nuclear power in the TBNW. To attain the more participation of nuclear weapons States, the TPNW furnishes provisions on general obligations of States Parties in declaration, ${ }^{61}$ safeguard measures, ${ }^{62}$ and cooperation towards the total elimination of nuclear weapons. ${ }^{63}$ Moreover, the TPNW has no provisions in detail on the procedure, rights and obligations, treatment and enforcement measures. Each State Party shall adopt the necessary measures to implement its obligations under the TPNW. ${ }^{64}$ It shall take all appropriate legal, administrative and other measures, including the imposition of penal sanctions, to prevent and suppress any activity prohibited to a State Party under the TPNW undertaken by persons or on territory under its jurisdiction or control. ${ }^{65}$ TPNW allows States, particularly nuclear weapons States to consider their own security interest in taking appropriate measures towards the total elimination of nuclear weapons, including the ratification of the TPNW. Nuclear weapon States would have time to put forth concrete proposals on disarmament measures before joining and planning to implement disarmament after accession to the TPNW. The "join then disarm" approach can help to reduce the tension between nuclear weapons States and others. The first goal is "get NWS to the negotiation table." "The ICRC and other NGOs can assist the governments concerned to amend and enact domestic legal acts in conformity with the TPNW. In case of Vietnam, some safeguard measures (Article 3) of the TPNW have been applied directly because they are in accordance

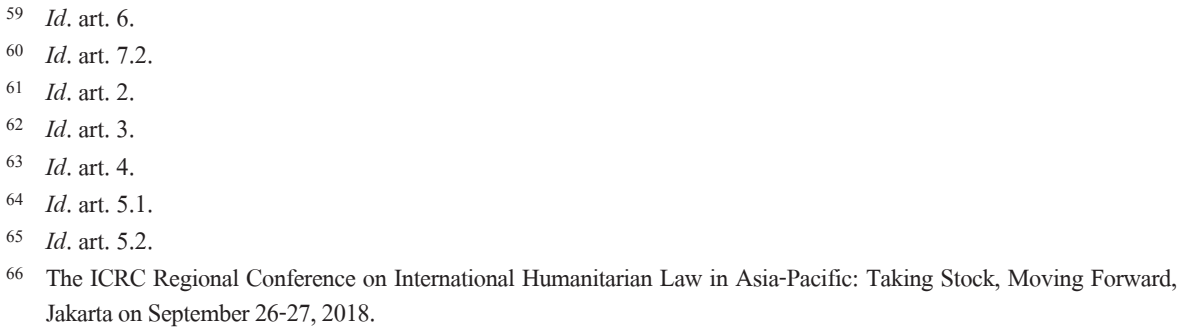


with the Law on Nuclear Energy and Agreement on safeguards and Additional Protocol to the Agreement concluded by Vietnam and the IAEA.

Finally, governments, NGOs and civil society across the world must make urgent pressure to the threat from emergence of new nuclear states and reduce the number of existing nuclear States through the TPNW, IHL and diplomacy. Together, hand by hand, States and international organizations, including the ICRC, will try to stop the use of nuclear weapons to save our planet for humankind, generations to generations. 
